\title{
PRODUCTIVE-ECONOMIC BENEFIT OF FORAGE CACTUS-SORGHUM INTERCROPPING SYSTEMS IRRIGATED WITH SALINE WATER ${ }^{1}$
}

\author{
LUCIVANIA RODRIGUES LIMA ${ }^{2}$, THIERES GEORGE FREIRE DA SILVA ${ }^{2 *}$, POLIANA DE CALDAS PEREIRA ${ }^{3}$, \\ JOSÉ EDSON FLORENTINO DE MORAIS ${ }^{4}$, MERY CRISTINA DE SÁ ASSIS ${ }^{2}$
}

\begin{abstract}
The objective of this study was to evaluate the productive and economic performance of a forage cactus and sorghum intercropping system in relation to a forage cactus single cropping system under different irrigation blades with saline water. The study was conducted in Serra Talhada, State of Pernambuco, in a randomized block design, consisting of a factorial arrangement with split-plot parcels $(5 \times 2)$ and four replications. The five plots were the irrigation depths based on the reference evapotranspiration (ETo) $(0,8.75$, $17.5,26.25$, and $35 \%$ ETo) and the two cropping systems were single forage cactus cropping and cactus intercropped with sorghum. The experiment was conducted for one year, with one forage cactus cycle and two cycles of sorghum. Yields were obtained at the end of the cycles. Economic profitability was analyzed by means of net revenue $(\mathrm{NR})$ and the benefit/cost ratio $(\mathrm{B} / \mathrm{C})$, with cactus forage sold as forage or as "seed" and sorghum as forage. Net revenue and $\mathrm{B} / \mathrm{C}$ simulations were carried out over an eight-year useful life span of the irrigation system. Increasing irrigation depth increased the dry matter yield of the intercropping system because of higher sorghum yield. Based on the NR and $\mathrm{B} / \mathrm{C}$ ratio values, forage cactus and sorghum produced as forage produced higher economic outcomes in the intercropping system and showed a higher profitability from the $2^{\text {nd }}$ year of implementation of the irrigation system. Forage cactus and sorghum intercropping irrigated with saline water is therefore recommended for forage production in the Brazilian semi-arid region.
\end{abstract}

Keywords: O. stricta (Haw.) Haw. Agronomic performance. Economic profitability.

\section{BENEFÍCIO PRODUTIVO-ECONÔMICO DO CONSÓRCIO PALMA FORRAGEIRA-SORGO IRRIGADO}

\begin{abstract}
RESUMO - Objetivou-se avaliar o desempenho produtivo-econômico da consorciação palma forrageira e sorgo em relação ao sistema de plantio exclusivo da palma forrageira sob diferentes lâminas de irrigação com água salina. A pesquisa foi conduzida em Serra Talhada, PE, com delineamento em blocos ao acaso, arranjo fatorial com parcelas subdivididas $(5 \times 2)$, quatro repetições, sendo considerada como parcelas as lâminas de irrigação complementar com base na evapotranspiração de referência $(0 ; 8,75 ; 17,5 ; 26,25$ e $35 \%$ ETo), e as subparcelas, os sistemas de plantio: palma exclusiva e consórcio palma-sorgo. O experimento foi conduzido por um ano, sendo um ciclo de palma e dois ciclos do sorgo. Ao final foram obtidas as produtividades de matéria fresca e seca. A rentabilidade econômica foi analisada por meio da receita líquida (RL) e da relação benefício/custo $(\mathrm{B} / \mathrm{C})$ da palma destinada à venda tanto para forragem como "semente" para o plantio, e do sorgo para produção de forragem. Simulações de RL e B/C foram feitas ao longo da vida útil de oito anos do sistema de irrigação. As lâminas de água aumentaram a produtividade de matéria seca do consórcio, devido ao benefício gerado ao sorgo. Com base na $\mathrm{RL}$ e B/C, verificou-se que a palma e o sorgo destinados à venda como forragem mostraram mais vantagem quando consorciadas e maior rentabilidade a partir do $2^{\circ}$ ano de implantação do sistema de irrigação. Conclui-se que, o consórcio palma forrageira e sorgo irrigado com água salina deve ser recomendado para a produção de forragem no Semiárido brasileiro.
\end{abstract}

Palavras-chave: O. stricta (Haw.) Haw. Desempenho agronômico. Rentabilidade econômica.

\footnotetext{
${ }^{*}$ Corresponding author

${ }^{1}$ Received for publication in 07/15/2016; accepted in 03/08/2017.

Paper extracted from the master's dissertation of the first author, funded by CNPq/FACEPE/IPA/UFRPE.

${ }^{2}$ Academic Unit of Serra Talhada, Universidade Federal Rural de Pernambuco, Serra Talhada, PE, Brazil; lucivania_rodrigues@hotmail.com,thieres_freire@yahoo.com.br, mcsamenezes@gmail.com.

${ }^{3}$ Department of Agricultural Engineering, Universidade Federal de Viçosa, Viçosa, MG, Brazil; po.caldas@hotmail.com.

${ }^{4}$ Universidade Federal Rural de Pernambuco, Recife, PE, Brazil; joseedson50@hotmail.com.
} 


\section{INTRODUCTION}

Forage cactus (Opuntia stricta) is the main food source for cattle, sheep and goat in the semi-arid region of Brazil, especially during the dry season. However, its productive performance is influenced by the seasonality of water availability and salt stress, which are common characteristics in semi-arid environments since the response of this crop depends on the type of cultivar, the salinity level of the water or soil, local climatic conditions, and other aspects associated with crop management (CONY; TRIONE; GUEVARA, 2006; DUBEUX JÚNIOR et al., 2006).

Studies have been carried out under field conditions in semi-arid environments with the forage cactus under supplementary irrigation (CONSOLI; INGLESE; INGLESE et al., 2013; FLORES-HERNÁNDEZ et al., 2004), although studies on the use of saline irrigation water are scarce (CONY; TRIONE; GUEVARA, 2006). Although the use of supplementary irrigation in forage cactus production system increases yields, studies with irrigation water from different depths, even in conditions of water salinity, are necessary to evaluate productivity (BARBOSA et al., 2012; LACERDA et al., 2011).

In this context, the use of intercropping systems also affects crop yield, mainly by influencing water, soil, and cropped area in addition to modifying pest-environment interactions, the occurrence of spontaneous plants, and productivity per unit area which, in most cases, is higher than in single cropping systems (MIRITI et al., 2012; SILVA et al., 2013). Forage cactus intercropped with other crops was tested in non-irrigated areas (SILVA et al., 2013); forage cactus was even intercropped with sorghum, which is tolerant to salt and water stress and therefore has a high capacity to adapt to semi-arid environments (GUIMARÃES et al., 2016; SILVA et al., 2013; SILVA et al., 2014). Thus, the adoption of forage cactus-sorghum intercropping, irrigated with saline water, may benefit the livestock industry of Brazilian semi-arid regions.

Setting up a production system depends on its agroeconomic performance, which allows to identify the advantages of adopting new management techniques via the net revenue and the benefit/cost ratio, thereby improving decision making, the control of productive resources, and their economic viability (ARAÚJO et al., 2008; SANTOS et al., 2009; VIEIRA et al., 2011).

The use of supplementary irrigation in intercropping has been reported in the literature for different cultivation configurations (BEZERRA et al., 2007; FAN et al., 2013). However, studies on this issue are not available for forage cactus; so far, only studies evaluating intercropping of this species under dry conditions have been performed (FARIAS et al., 2000; SILVA et al., 2013).
In this study, we tested the hypothesis that the adoption of supplementary irrigation, although with saline water, combined with forage cactus-sorghum intercropping, significantly increases productivity and profitability of the forage cactus cultivation system. The objective of this study was to evaluate the economic performance of the forage cactus-sorghum intercropping system in relation to the single cropping system of forage cactus at different saline water depths in the Brazilian semi-arid region.

\section{MATERIAL AND METHODS}

The study was carried out in the municipality of Serra Talhada, state of Pernambuco (latitude: $7^{\circ} 59^{\prime} \mathrm{S}$, longitude: $38^{\circ} 15^{\prime} \mathrm{W}, 431 \mathrm{~m}$ above sea level), in the microregion of Pajeú Valley, Brazilian semi-arid region. The area with forage cactus, Opuntia stricta (Haw.) Haw., was set up in March 2011. Prior to planting the soil was harrowed and furrowed, with $1.6 \times 0.2 \mathrm{~m}$ holes, and the cladodes were planted with $50 \%$ of their lengths buried. Until late May 2012, the crop was conducted under a single cropping system and in dry conditions. On this occasion, the first cut was carried out, leaving only the basal cladodes, and the second productive cycle was started, which represented the experimental period of the present study, by establishing a drip irrigation system. Irrigation was conducted for 380 days until June 2013, representing one productive year.

The experimental design consisted of a randomized block design with a $5 \times 2$ split plot, with four replications. The plots were composed of four supplementary irrigation depths based on the fractions of control evapotranspiration (ETo) (8.75, 17.5, 26.25, and $35 \%$ ETo) at the time of differentiation plus the control ( $0 \%$. ET, dry area); subplots were composed of two planting systems (single forage cactus system and forage cactus-sorghum intercropping). The five irrigation depths based on ETo fractions were defined from the mean crop coefficient value (0.40) obtained by Consoli, Inglese and Inglese (2013) for the 10-year-old forage cactus O. ficus-indica L. (Mill.) in Sicily, Italy. Each experimental subplot had four rows of $6 \mathrm{~m}$ in length and 15 plants, totaling 60 plants and a total area of $38.4 \mathrm{~m}^{2}$. The plants in the two central rows, disregarding the two plants on each side, were considered as a useful area of $12.8 \mathrm{~m}^{2}$, containing 22 plants. Total experimental area was $1,536 \mathrm{~m}^{2}$, with 40 experimental subplots.

The intercropping system was established in November 2012 by inserting double aptitude forage sorghum (Sorghum bicolor (L.) Moench), cv. IPA2502, spaced by $0.25 \mathrm{~m}$ from the forage cactus row. For the planting of the sorghum, continuous holes of $6 \mathrm{~m}$ in length and with a depth of $0.05 \mathrm{~m}$ 
were opened and 18 seeds per linear meter were planted. The sorghum was conducted for two productive cycles, one of the plant and the one of the regrowth, with harvesting being carried out in February 2013 and June 2013, totaling 246 cultivation days among the 380 days of the forage cactus cycle.

Irrigation was carried out every two days via a drip system, running on the basis of estimated irrigation time from the mean flow rate of $1.35 \mathrm{~L} \mathrm{~h}^{-1}$ under the pressure of $1.0 \mathrm{~atm}$, spacing (1.6 x $0.4 \mathrm{~m})$, and system efficiency (mean of Christiansen Uniformity Coefficient - CUC $=91 \%$; distribution uniformity coefficient - DUC $=95 \%$ ) in periods when rainfall was lower than the ETo accumulated between the days of water replenishment in the soil. The ETo was estimated by the Penman Monteith method, parameterized in FAO bulletin 56 (ALLEN et al., 1998), using weather data obtained from an automatic station of the National Institute of Meteorology - INMET, set in the municipality of Serra Talhada, less than $1,500 \mathrm{~m}$ from the experimental area.

Soil moisture was monitored over time by a locally calibrated capacitive probe (Diviner@2000 Sentek Pty Ltda., Australia) as described by Araújo Primo et al. (2015). Access pipes were installed in each of the 40 subplots and measurements were taken at two-day intervals up to a depth of $0.60 \mathrm{~m}$.

To guarantee initial crop establishment, differentiation of the irrigation depths occurred from December 2012 (one month after planting sorghum) until June 2013, when the forage cactus and sorghum harvest took place in the regrowth cycle. The irrigation depths with saline water $(583,655$, 703, 759, and $809 \mathrm{~mm}$ year $^{-1}$ ) plus rainfall (393 $\mathrm{mm} \mathrm{year}^{-1}$ ) totaled the equivalent to $976,1,048$, $1096,1,152$, and $1,202 \mathrm{~mm} \mathrm{year}^{-1}$ at the end of the experiment. For irrigation, water from Açude Saco, in the vicinity of the experimental area, was used; electrical conductivity ranged from 1.1 to $1.6 \mathrm{dS} \mathrm{m}^{-1}$ throughout the crop cycle.

Further, we used a 14-00-18 formulated broadcast fertilization in a monthly interval, according to the recommendations of the Agronomic Institute of Pernambuco, in addition to weeding and phytosanitary controls whenever necessary.

Forage cactus yield was estimated in tons per hectare $\left(\mathrm{t} \mathrm{ha}^{-1}\right)$, considering fresh matter, total weight, and number of plants of the experimental plot area; final density of plants at the time of harvest was determined $\left(15,625\right.$ plants $\left.h^{-1}\right)$. The dry matter content was used to obtain yield on a dry basis. The number of cladodes per plant was determined and extrapolated to hectare, as suggested by Silva et al. (2015). For sorghum, we measured the fresh weight of 10 plants, final plant density by counting the number of individuals per linear meter at the time of harvesting in the plant and regrowth cycles, and dry matter content. The productive performance of the intercropping system was expressed as the sum of the yields of the forage cactus plus yields obtained in the two sorghum cycles, according to Farias et al. (2000).

Economic profitability of the adoption of the palm-sorghum intercropping was estimated in terms of costs of the implantation and maintenance of the two crops and the drip irrigation system, both for an area of one hectare.

Further, we considered the costs of planting sorghum (purchase of seeds and labor for planting) as well as of weeding and fertilization. The costs of the components of the irrigation system were surveyed in three agricultural product trades, obtaining the average values of each component and the final fixed costs of planting one hectare. Based on this data, we calculated the variable costs: depreciation of the system components (DC), interest on the invested capital (IC), power variable costs (PVC), labor costs (LC), maintenance of system components (MSC), and contingency reserve (CR).

Calculation of the depreciation costs of the equipment followed the methodology suggested by Fernandes, Santinato and Fernandes (2008), who evaluated the values of the components in the trade; the residual or scrap value, considering that $20 \%$ of the purchase value of each component were withdrawn in addition to the 15 -year useful life span of the equipment, by means of the following equation:

$$
\mathrm{DC}=\frac{[(\mathrm{CAV})-(0.2 \times \mathrm{CAV})]}{\mathrm{UL}},
$$

where, DC = depreciation of the system component $(\mathrm{R} \$) ; \mathrm{CAV}=$ component acquisition value $(\mathrm{R} \$)$; $0.2 \times \mathrm{CAV}=$ scrap or residue value $(\mathrm{R} \$)$; $\mathrm{UL}=$ useful life span (years).

The cost of interest on invested capital was recorded considering the savings income bank rate, which is around $7.2 \%$ per year, and the acquisition value of equipment purchased in the trade, that is, the initial investment for implementation of the irrigation system, according to the following equation:

$$
\mathrm{IC}=\mathrm{AIR} \times \mathrm{PAE},(2)
$$

where IC $=$ interest on invested capital $(\mathrm{R} \$)$; $\mathrm{AIR}=$ annual interest rate $(\%)$; and $\mathrm{PAE}=$ purchase value for equipment $(R \$)$.

When calculating electricity costs for water pumping, we obtained the value of kilowatt-hours (kWh) charged by the government energy company $(\mathrm{R} \$=0.42 \mathrm{kWh})$, assuming a fee for rural areas, the time in annual hours of equipment operation (average $444 \mathrm{~h} \mathrm{year}^{-1}$ ), and the required power of the motor pump assembly ( $2 \mathrm{hp}$ ), considering the efficiency of the pump and the electric motor, according to the equation:

$$
\mathrm{CEP}=\mathrm{V}_{\mathrm{kwh}} \times \mathrm{T} \times\left(\frac{736 \times \mathrm{Pot}}{1000 \times \eta}\right)
$$

where, $\mathrm{CEP}=$ costs of electrical power $(\mathrm{R} \$)$, 
$\mathrm{V}_{\mathrm{KWh}}=\mathrm{kWh}$ value $(\mathrm{R} \$), \mathrm{T}=$ irrigation system total operation time (h), varying for each $t$ reatment, Pot $=$ engine-pump set power $(\mathrm{cv})$, and $\eta=$ pump-engine set yield (decimal).

To calculate labor expenses in the maintenance of the irrigation system, we considered the area in hectare, the number of employees needed for one hectare irrigated by the drip system (0.04 men ha $\left.{ }^{-1}\right)$, and the current Brazilian minimum wage, including the taxes charged by the government, according to the following formula (FERNANDES; SANTINATO; FERNANDES, 2008):

$$
\mathrm{ALC}=\mathrm{SA} \times \mathrm{ARS} \times \mathrm{MW},
$$

where $\mathrm{ALC}=$ annual labor cost $(\mathrm{R} \$), \mathrm{SA}=$ system of the area (ha), ARS = average labor requirement (number of workers per ha), and MW = current Brazilian minimum wage, including tax charges (R\$).

Costs of annual maintenance of the components of the drip irrigation system were accounted by using average percentage values for the maintenance of each component of the system: buried pipes $(0.5 \%)$, surface pipes $(1 \%)$, structures $(1.5 \%)$, motor pumps $(6 \%)$, emitters $(7 \%)$, and filters $(8 \%)$. For this calculation, the purchase value of each component in the trade was added, according to Fernandes, Santinato and Fernandes (2008), using the following equation:

$$
\mathrm{SCM}=\mathrm{PVM} \times \mathrm{CPV}
$$

where $\mathrm{SCM}=$ annual cost of system components maintenance ( $\mathrm{R} \$), \mathrm{PVM}=$ average percentage value for maintenance of system components (decimal), and $\mathrm{CPV}=$ component purchase value $(\mathrm{R} \$)$.
The contingency reserve used for emergency cases caused by human, mechanical, or system failures was calculated by adding $5 \%$ to the variable costs, such as depreciation of the system components, interest on the invested capital, costs of electric power, labor and maintenance of the system components (FERNANDES; SANTINATO; FERNANDES, 2008).

Subsequently, the total cost of irrigation system implantation was obtained, according to the equation:

$$
\mathrm{TC}=\sum(\mathrm{FC}+\mathrm{VC})
$$

where

$\mathrm{TC}=$ total cost of irrigation system implantation, $\mathrm{FC}=$ fixed costs, and $\mathrm{VC}=$ variable costs.

Expenses related to water consumption were not considered because the water grant has still not been charged in the municipality of Serra Talhada.

The economic viability of irrigation and the adoption of the forage cactus-sorghum intercropping was analyzed by comparing the net revenue (RL) and the benefit/cost ratio $(\mathrm{B} / \mathrm{C})$, equivalent to one hectare, in relation to the single forage cactus cropping system.

The net revenues of single cropping (forage cactus) and intercropping (cactus-sorghum) systems were obtained from the difference between the gross revenue (considering the destination of cactus production for forage or the use as "seed" for planting new areas and sorghum solely for sale as forage) and the total costs of implementation and maintenance costs, corresponding to each planting system, in addition to the implementation of the irrigation system, according to the following equations:

$$
\begin{gathered}
\mathrm{NR}_{\text {(singlesystem) }}=\mathrm{GR}_{\text {cactus(forage) }}-\sum(\mathrm{CS}+\mathrm{TC}) \\
\mathrm{NR}_{\text {(singlesystem) }}=\mathrm{GR}_{\text {cactus("seed") }}-\sum(\mathrm{CS}+\mathrm{TC}) \\
\mathrm{NR}_{\text {(intercroppingsystem) }}=\mathrm{GR}_{\text {cactus(forage)+sorghum(frage) }}-\sum(\mathrm{CS}+\mathrm{TC}) \\
\mathrm{NR}_{\text {(intercroppingsystem) }}=\mathrm{RB}_{\text {cactus("seed")+sorghum(frage) }}-\sum(\mathrm{CS}+\mathrm{TC}),
\end{gathered}
$$

where $\mathrm{NR}_{\text {(single system) }}$ and $\mathrm{NR}_{\text {(intercropping system) }}=$ net revenue of the single cropping and intercropping systems, at that order; $\mathrm{GR}_{\text {cactus(forage), }}$ $\mathrm{RB}_{\text {cactus("seed"), }} \mathrm{RB}_{\text {cactus(forage)+sorghum (forage), and }}$ $\mathrm{RB}_{\text {cactus ("seed")+sorghum (forage) }}=$ gross income of the forage intended for sale as forage or as "seed" and cactus plus sorghum for sale as forage, or cactus as "seed" and sorghum as forage, respectively; $\mathrm{CS}=$ implementation costs of each planting system (single and intercropping); and $\mathrm{TC}=$ total cost of irrigation system implementation.

Gross income was calculated for the forage cactus intended for forage and as "seed", assuming a market value of the cactus for the destination as forage of R\$ $100.00 \mathrm{t} / \mathrm{ha}$, a market value of sorghum residue of $\mathrm{R} \$ 150.00 \mathrm{t}$ plus grains of $\mathrm{R} \$ 0.80 \mathrm{~kg}$, while the market value of cladode for sale as "seed" for planting was R \$ 0.15 per unit. In this case, we considered that only $1^{\text {st }}$ and $2^{\text {nd }}$ order cladodes were intended for sale.

Economic profitability calculations of the adoption of the intercropped forage cactus-sorghum system under irrigation were performed for the five supplementary irrigation depths.

Data on fresh and dry matter yield and total number of cladode per plant were submitted to the normality test and analysis of variance ( $F$ test). In the case of significance and with interaction between the factors, the variables were subjected to the LSD (Least significant Difference, 5\%) test.

Simulations of the NR and $\mathrm{B} / \mathrm{C}$ ratio were performed between the $2^{\text {nd }}$ and $8^{\text {th }}$ year of irrigation, aimed at identifying the NR moments with an advantage of at least $10 \%$, that is, $\mathrm{B} / \mathrm{C}$ ratio $>1.10$. In this case, it took up to eight years, which represents the useful life span of a drip irrigation 
system. In addition, annual harvests with a productivity equal to that of the $1^{\text {st }}$ year were considered, maintaining the basal cladodes. Overall total costs, variable and cultivation treatment expenses, and the selling prices of the products changed over the years based on the interest rates, as previously mentioned.

\section{RESULTS AND DISCUSSION}

A.

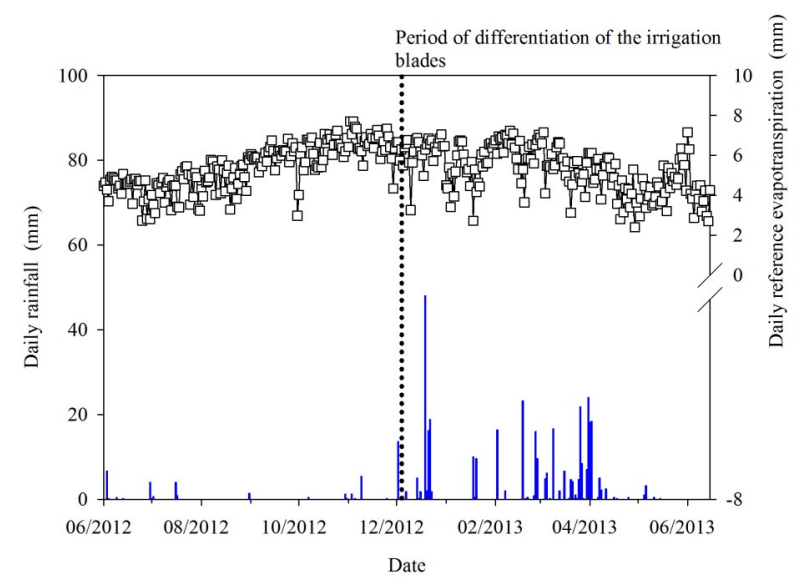

C.

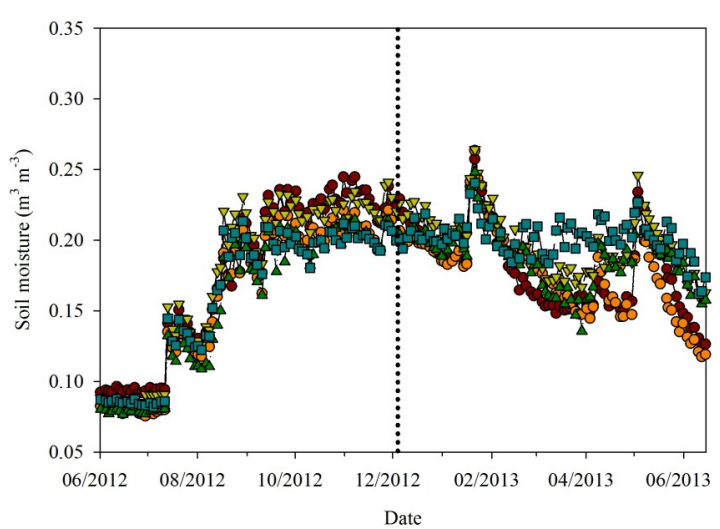

Rainfall and reference evapotranspiration are shown in Figure 1A. Most rainfall events occurred during the period of irrigation depth differentiation. Therefore, there was little difference between the accumulated irrigation depths, reaching a maximum of $226 \mathrm{~mm}$ (Figure 1B), which was sufficient to promote changes in soil moisture $(\theta)$ (Figure 1C, D). The $\theta$ presented smaller amplitudes between the irrigation depths in the single cropping system when compared to the intercropping system, in which the water dynamics is more effective because of the presence of the root systems of the two crops.

B.

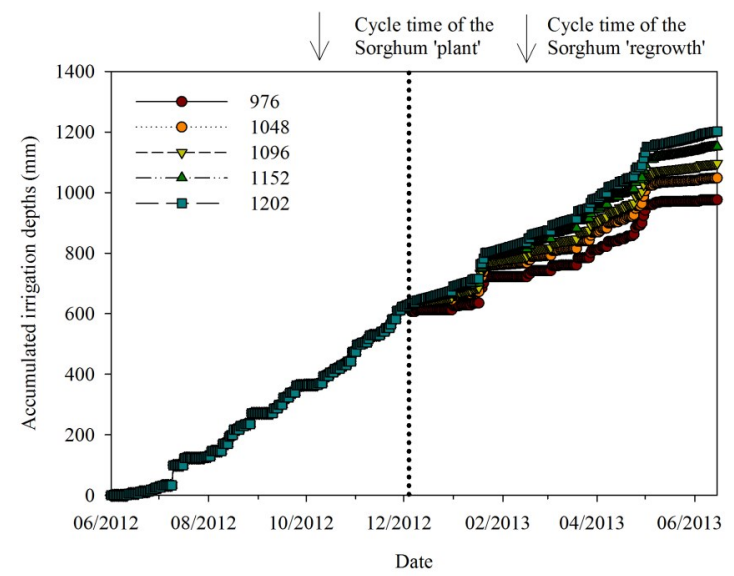

D.

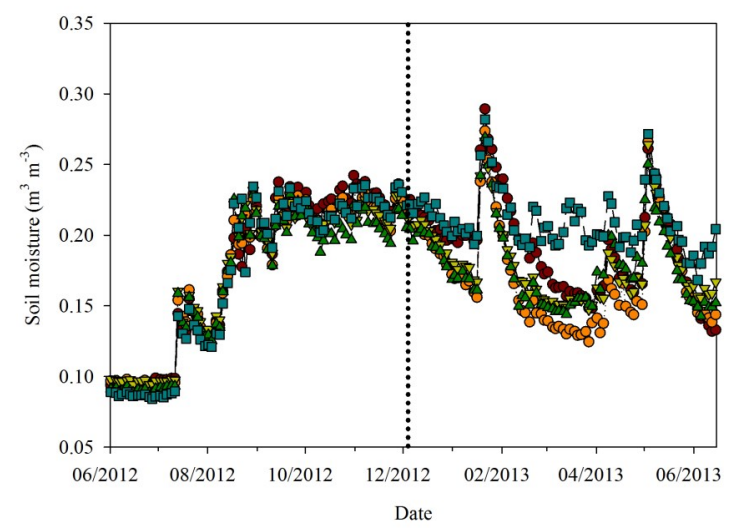

Figure 1. Daily rainfall and reference evapotranspiration (A), accumulated irrigation depths (B), and forage cactus $(O$. stricta (Haw.) Haw.) cropped soil moisture content in the single cropping system (C) and in forage cactus and sorghum intercropping (D) under five additional irrigation depths with saline water plus rainfall $(976,1,048,1,096,1,152$, and $1,202 \mathrm{~mm}$ year $^{-1}$ ).

Irrigation depth affected fresh and dry matter yields of the crop residue and of the double aptitude sorghum grains. Dry matter yield of the intercropping system (cactus + sorghum) was influenced by the interaction between the factors as well as by their isolated effects. Individual productivity of the forage cactus in terms of fresh matter was affected only by the cropping system (Table 1).

Increased water depth resulted in higher fresh matter, dry matter, and grain yields of the double aptitude sorghum intercropped with cactus
(Figure 2).

Total residue fresh matter yield over the two cycles intercropped with cactus, regardless of the supplementary irrigation blade, was 45.77 tons $\mathrm{ha}^{-1}$, while dry matter and grain yields were equal to 12.10 tons $\mathrm{ha}^{-1}$ and 5.57 tons $\mathrm{ha}^{-1}$, respectively. These values are higher than those reported by Farias et al. (2000), who also analyzed cactus-sorghum intercropping (654.6 mm year $\left.{ }^{-1}\right)$. Sorghum is a crop with a high productive response to increasing irrigation depths, as verified by Silva et al. $(2013,2014)$ and Guimarães et al. (2016) in 
response to the application of saline water and fish culture waste, respectively. In addition, the use of such types of water increases the electrical conductivity of the aqueous extract of the soil under low irrigation depths, resulting in higher salinity in the first soil layers and, consequently, additive effects of water and salt stress on agronomic crop performance (SILVA et al., 2013; GUIMARÃES et al., 2016).

Table 1. Summary of the analysis of variance of productive performance of forage double aptitude sorghum and forage cactus in single cropping and intercropping systems.

\begin{tabular}{|c|c|c|c|c|c|c|c|c|c|}
\hline \multirow[b]{2}{*}{ S.V. } & \multirow[b]{2}{*}{ F.D. } & \multicolumn{8}{|c|}{ Mean square } \\
\hline & & $\mathrm{FM}_{\text {res. }}$ & $\mathrm{DM}_{\text {res. }}$ & GR & $\mathrm{FM}_{\mathrm{p}}$ & $\mathrm{DM}_{\mathrm{p}}$ & $\mathrm{FM}_{\mathrm{p}+\mathrm{s}}$ & $\mathrm{DM}_{\mathrm{p}+\mathrm{s}}$ & NTC \\
\hline Block & 3 & $41,899.2 *$ & $2,911.4^{*}$ & $617.6^{*}$ & $524,547.6^{*}$ & $2,117.9^{*}$ & $662,138.8^{*}$ & $7,085.3^{*}$ & $6,870.1^{*}$ \\
\hline WD & 4 & $661.6^{*}$ & $127.4^{*}$ & $26.8^{*}$ & $344.4^{\mathrm{ns}}$ & $3.4^{\mathrm{ns}}$ & $465.6^{\mathrm{ns}}$ & $41.5^{*}$ & $6.9^{\mathrm{ns}}$ \\
\hline $\mathrm{CS}$ & 1 & - & - & - & $11,100.0^{*}$ & $31.3^{\mathrm{ns}}$ & $252.6^{\mathrm{ns}}$ & $1,060.0^{*}$ & $41.4^{\mathrm{ns}}$ \\
\hline $\mathrm{LI} * \mathrm{SP}$ & 4 & - & - & - & $681.5^{\mathrm{ns}}$ & $2.0^{\mathrm{ns}}$ & $1,670.0^{\mathrm{ns}}$ & $74.5^{*}$ & $8.4^{\mathrm{ns}}$ \\
\hline Residue & 30 & 180.0 & 6.6 & 1.4 & $2,365.0$ & 8.3 & $2,514.9$ & 13.8 & 17.6 \\
\hline
\end{tabular}

SV - Sources of variation; WD - Water depth; CS - Cropping system; $\mathrm{FM}_{\text {res. }}$ - Sorghum residue fresh matter yield $\left(\mathrm{t} \mathrm{ha}^{-1}\right) ; \mathrm{DM}_{\text {res. }}$ - Sorghum residue dry matter yield $\left(\mathrm{t} \mathrm{ha}^{-1}\right)$; GR - Grains $\left(\mathrm{t} \mathrm{ha}^{-1}\right) ; \mathrm{FM}_{\mathrm{p}}-$ Forage cactus individual fresh matter yield $\left(\mathrm{t} \mathrm{ha}^{-1}\right) ; \mathrm{DM}_{\mathrm{p}}$ - Forage cactus individual dry matter yield $\left(\mathrm{t} \mathrm{ha}^{-1}\right) ; \mathrm{FM}_{\mathrm{p}+\mathrm{s}}-$ Sorghum-forage cactus fresh matter yield $\left(\mathrm{t} \mathrm{ha}^{-1}\right) ; \mathrm{DM}_{\mathrm{p}+\mathrm{s}}$ - Sorghum-forage cactus intercropping dry matter yield $\left(\mathrm{t} \mathrm{ha}^{-1}\right)$; NTC - Total number of cladodes (units ha ${ }^{-1}$ ) ${ }^{\text {ns }}$ - non-significant, $*$ - significant at $5 \%$ by the $\mathrm{F}$ test.

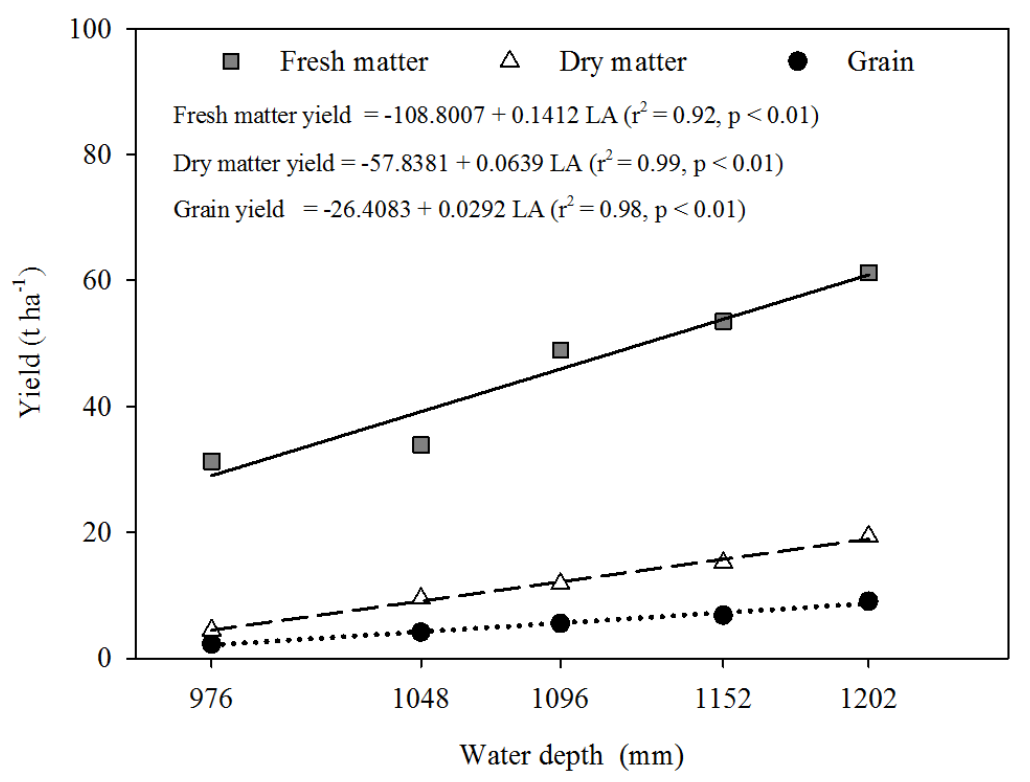

Figure 2. Effects of supplementary irrigation depths with saline water plus rainfall $(976,1,048,1,096,1,152$, and $\left.1,202 \mathrm{~mm} \mathrm{year}^{-1}\right)$ on fresh and dry matter as well as grain yields of double aptitude sorghum intercropped with forage cactus (O. stricta (Haw.) Haw.).

The average yield of irrigated forage cactus was 114.5 tons FM ha ${ }^{-1}$ year $^{-1}$ and 7.3 tons $\mathrm{DM} \mathrm{ha}^{-1}$ year $^{-1}$, which may be associated with the low water requirement of this cactus species during the first year of growth. Similarly, Flores-Hernández et al. (2004) also observed a lack of an effect of the supplementary irrigation depths on the cactus planting system in four clones of different Opuntia species (C-8, C-40, C-60, and C-69), irrigated with $740,1,060$, and $1,380 \mathrm{~mm} \mathrm{year}^{-1}$ depths in the municipality of Gómez Palácio in Durango, Mexico. In a similar study, Consoli, Inglese and Inglese (2013) observed increased annual productivity of forage cactus with irrigation. Previous studies have shown positive crop performance despite the use of saline irrigation water
(BARBOSA et al., 2012; LACERDA et al., 2011; SILVA et al., 2014), including forage cactus (CONY; TRIONE; GUEVARA, 2006).

On the other hand, intercropping reduced cactus fresh matter production (Figure 3), possibly due to competition for light and nutrients; under such intercropping configuration (cactus-sorghum), it is expected that cactus, in relation to sorghum (C4 plant), consumes more water during the night and during the day, with a compensatory effect on the water use or partition between evaporation and transpiration in the intercropping system. Albuquerque and Rao (1997) also observed reductions in individual crop yields in cactus-sorghum and cactus-beans intercropping under dry conditions. 


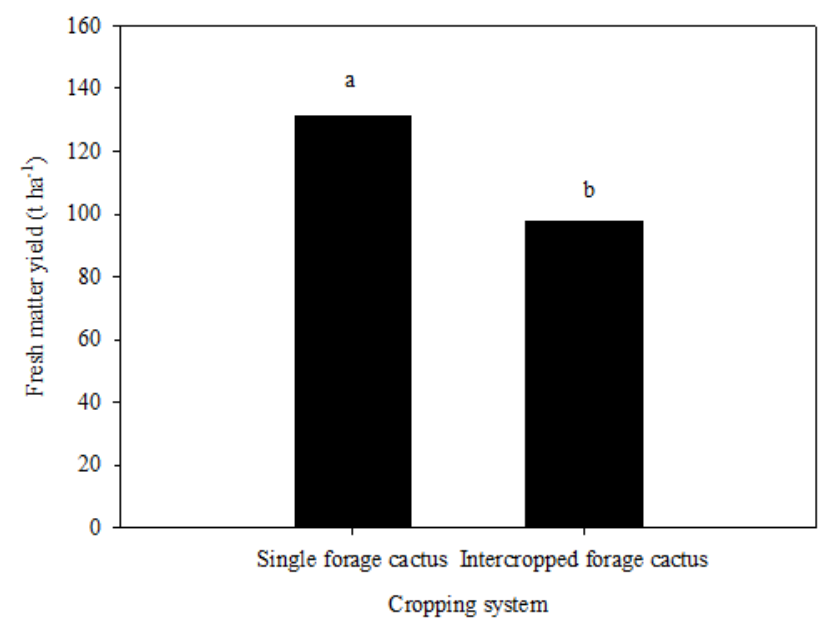

Figure 3. Individual fresh matter yield of forage cactus (O. stricta (Haw.) Haw.) in the single cropping system and intercropped with double aptitude sorghum, under five additional irrigation depths with saline water plus rainfall (976, $1,048,1,096,1,152$, and 1,202 $\left.\mathrm{mm}_{\text {year }}{ }^{-1}\right)$.

Although intercropping affected the individual yield of forage cactus, its adoption combined with the use of saline water irrigation significantly increased the dry matter yield of the production system (Figure 4A, B), mainly due to the performance of the sorghum crop (Figure 1). Fan et al. (2013) stated that the increase in the irrigation depth in intercropping systems improves the water supply, thereby reducing competition for water and nutrients and favoring overall productivity of the area.
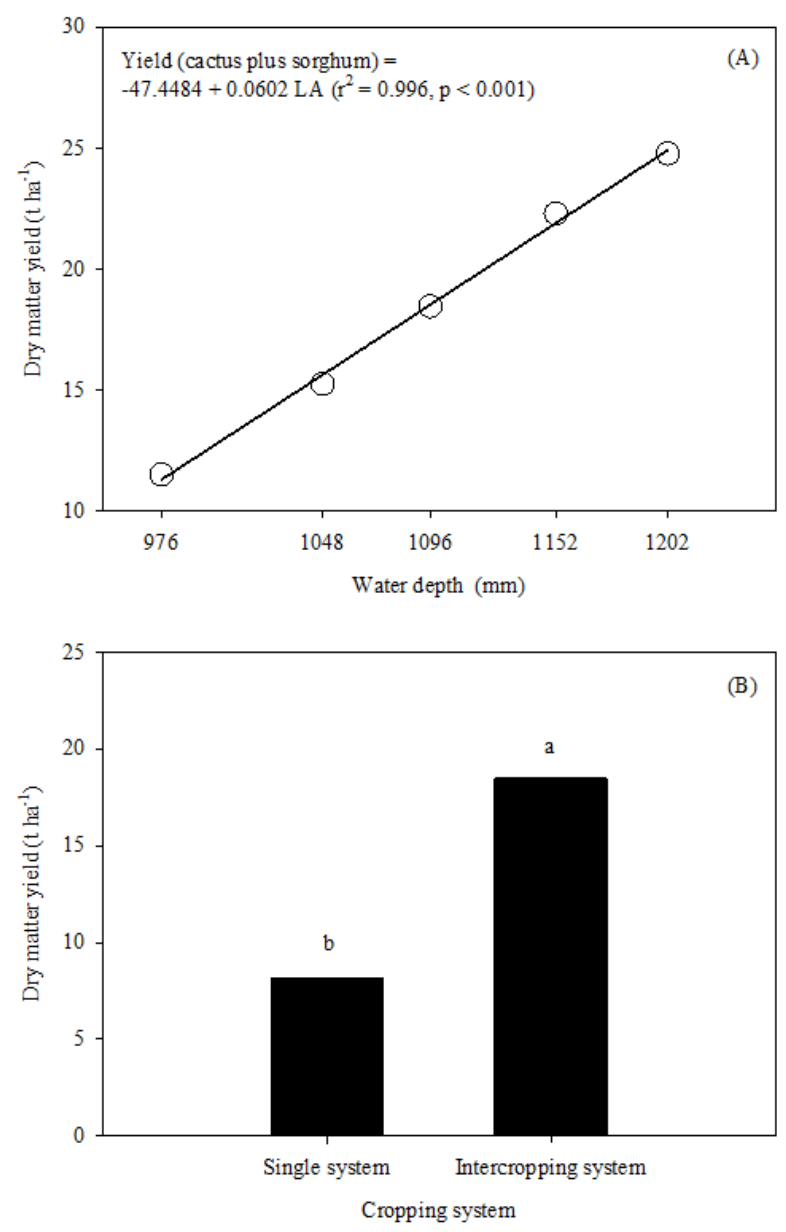

Figure 4. Effects of supplementary irrigation depths with saline water plus rainfall $(976,1,048,1,096,1,152$, and $1,202 \mathrm{~mm} \mathrm{year}^{-1}$ ) (A) and cropping system (B) on dry matter yield. 
In the present study, the productive potential of the cactus-sorghum intercropping system was increasing until the water depth of $1202 \mathrm{~mm}$ depths year $^{-1}$ (Table 2), that is, a productive year of forage cactus with two cycles of sorghum increased dry matter yield by $260 \%$. The productive advantage of the intercropping system in relation to single cropping has been highlighted in the literature in terms of increased production per unit of area, despite the reduction in individual productivity of both crops (MIRITI et al., 2012; SILVA et al., 2013).

Table 2. Interaction of the supplementary irrigation depths with saline water plus rainfall $(976,1,048,1,096,1,152$, and $1,202 \mathrm{~mm} \mathrm{year}^{-1}$ ) and cropping systems (single and forage cactus-sorghum intercropping) on dry matter yield, in tons ha ${ }^{-1}$.

\begin{tabular}{crcccr}
\hline & \multicolumn{5}{c}{ Water depth $\left(\mathrm{mm} \mathrm{year}^{-1}\right)$} \\
\cline { 2 - 6 } Cropping system & 976 & 1,048 & 1,096 & 1,152 & 1,202 \\
\hline Single & $8.71 \mathrm{Aa}$ & $9.13 \mathrm{Ba}$ & $8.33 \mathrm{Ba}$ & $7.72 \mathrm{Ba}$ & $6.91 \mathrm{Ba}$ \\
Intercropping & $11.52 \mathrm{Ad}$ & $15.25 \mathrm{Acd}$ & $18.46 \mathrm{Abc}$ & $22.29 \mathrm{Aab}$ & $24.77 \mathrm{Aa}$ \\
\hline
\end{tabular}

Means followed by the same upper case letter within a column and lower case letter within a row are not significantly different according to the LSD test (\%).

The total number of cladodes (TNC) of the cactus was not affected by water depth and cropping system, with the total produced cladodes being 205,000 ud ha ${ }^{-1}$, with a final density of 15,625 plants $\mathrm{ha}^{-1}$. Dubeux Júnior et al. (2006) observed for cv. IPA 20, in a single cropping system and under dry conditions $\left(600 \mathrm{~mm} \mathrm{year}^{-1}\right)$ in the municipality of Serra Talhada, state of Pernambuco, TNC values of $260,000 \mathrm{ud} \mathrm{ha}^{-1}$, under a population density of $40,000 \mathrm{ha}^{-1}$ plants during one cycle (two years). In a similar study, Silva et al. (2015) obtained almost 441,000 ud ha ${ }^{-1}$ for the Mexican elephant ear, with a final density of 30,938 plants $\mathrm{ha}^{-1}$, in dry conditions and at two years of age (732 mm year $\left.{ }^{-1}\right)$, also in the municipality of Serra Talhada, state of
Pernambuco, demonstrating the high cladode emission capacity of this clone.

In terms of economic viability, the total values from fixed and variable costs and from expenditures resulting from the insertion of the intercropping system during a productive year varied slightly between the supplementary irrigation depths of $583 \mathrm{~mm}$ year $^{-1}(\mathrm{R} \$ 12,422.67)$ and $809 \mathrm{~mm}$ year $^{-1}$ (R\$ 12,563.63). In the single cropping system, the maximum cost also occurred for the replacement of $809 \mathrm{~mm}$ year $^{-1}$ (R\$ 12,033.63), differing only by $-4.2 \%$ in costs compared to the intercropping system for the same depth (Table 3); in other words, the implementation of cactus-sorghum intercropping is not associated with significantly higher costs.

Table 3. Costs (R\$, Brazilian currency) of implementation of forage cactus (O. stricta (Haw.) Haw.) single cropping and intercropping with double aptitude forage sorghum (cv. IPA2502); different supplementary irrigation depths with saline water plus rainfall $\left(976,1,048,1,096,1,152\right.$, and 1,202 $\left.\mathrm{mm} \mathrm{year}^{-1}\right)$.

\begin{tabular}{|c|c|c|c|c|c|}
\hline \multirow[t]{2}{*}{ System } & \multicolumn{5}{|c|}{ Supplementary irrigation depth + rainfall } \\
\hline & $\begin{array}{c}976 \\
\text { mm year }^{-1}\end{array}$ & $\begin{array}{c}1,048 \\
\text { mm year }^{-1}\end{array}$ & $\begin{array}{c}1,096 \\
\text { mm year }^{-1}\end{array}$ & $\begin{array}{c}1,152 \\
\text { mm year }^{-1}\end{array}$ & $\begin{array}{c}1,202 \\
\text { mm year }^{-1}\end{array}$ \\
\hline \multicolumn{6}{|c|}{ Single cropping } \\
\hline Fixed costs & $5,760.40$ & $5,760.40$ & $5,760.40$ & $5,760.40$ & $5,760.40$ \\
\hline Variable costs & $2,092.27$ & $2,137.79$ & $2,167.16$ & $2,202.40$ & $2,233.23$ \\
\hline Crop management & $4,040.00$ & $4,040.00$ & $4,040.00$ & $4,040.00$ & $4,040.00$ \\
\hline Total & $11,892.67$ & $11,938.19$ & $11,967.56$ & $12,002.80$ & $12,033.63$ \\
\hline \multicolumn{6}{|c|}{ Intercropping } \\
\hline Fixed costs & $5,760.40$ & $5,760.40$ & $5,760.40$ & $5,760.40$ & $5,760.40$ \\
\hline Variable costs & $2,357.27$ & $2,402.79$ & $2,432.16$ & $2,467.40$ & $2,498.23$ \\
\hline Crop management & $4,040.00$ & $4,040.00$ & $4,040.00$ & $4,040.00$ & $4,040.00$ \\
\hline Sorghum implementation & 265.00 & 265.00 & 265.00 & 265.00 & 265.00 \\
\hline Total & $12,422.67$ & $12,468.19$ & $12,497.56$ & $12,532.80$ & $12,563.63$ \\
\hline
\end{tabular}


Economic profitability varied according to the purpose of the product. In the single cropping system, in which the cactus was grown for sale as forage (Figure 5A, C), we observed a tendency to reduce net income $(\mathrm{NI})$ and the benefit/cost ratio $(\mathrm{B} / \mathrm{C})$ as irrigation depths increased. In contrast, in the intercropping system, in which cactus and sorghum were sold as forage, higher economic returns were achieved with supplementary irrigation depths, with the $\mathrm{B} / \mathrm{C}$ ratio reaching values close to 1.0. In these cases, the adoption of irrigated single or cactus-sorghum intercropping systems results in $\mathrm{B} / \mathrm{C}$
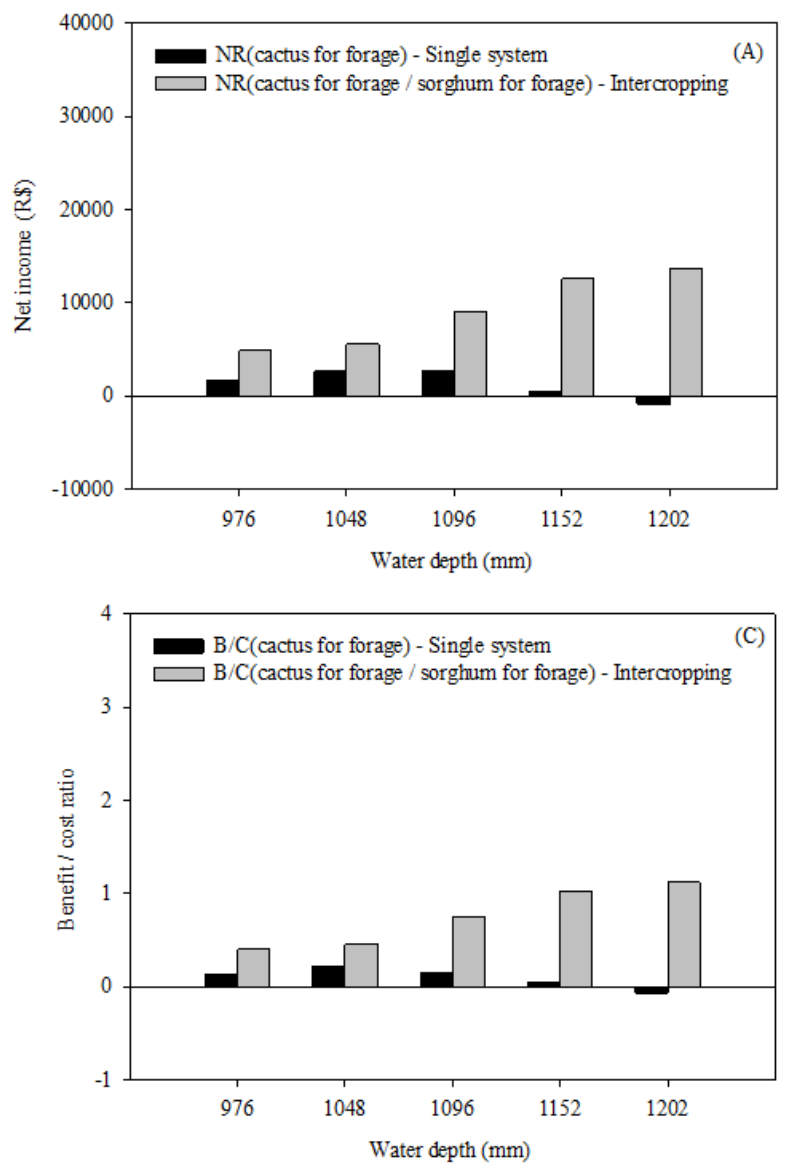

values lower than 1.0, indicating that revenues are lower than production costs, rendering the implementation of the irrigation system for only one year unfeasible (ARAÚJO et al., 2008; SANTOS et al., 2009; VIEIRA et al., 2011).

By simulating costs and revenues up to the $8^{\text {th }}$ operation year of the drip irrigation system, we estimated that in the second year, the $\mathrm{B} / \mathrm{C}$ values will be higher than 1.1, showing a profitability of at least $10 \%$ within a short implementation time. In addition, the adoption of the intercropping system generated even greater economic returns $(\mathrm{B} / \mathrm{C}>1.5)$.
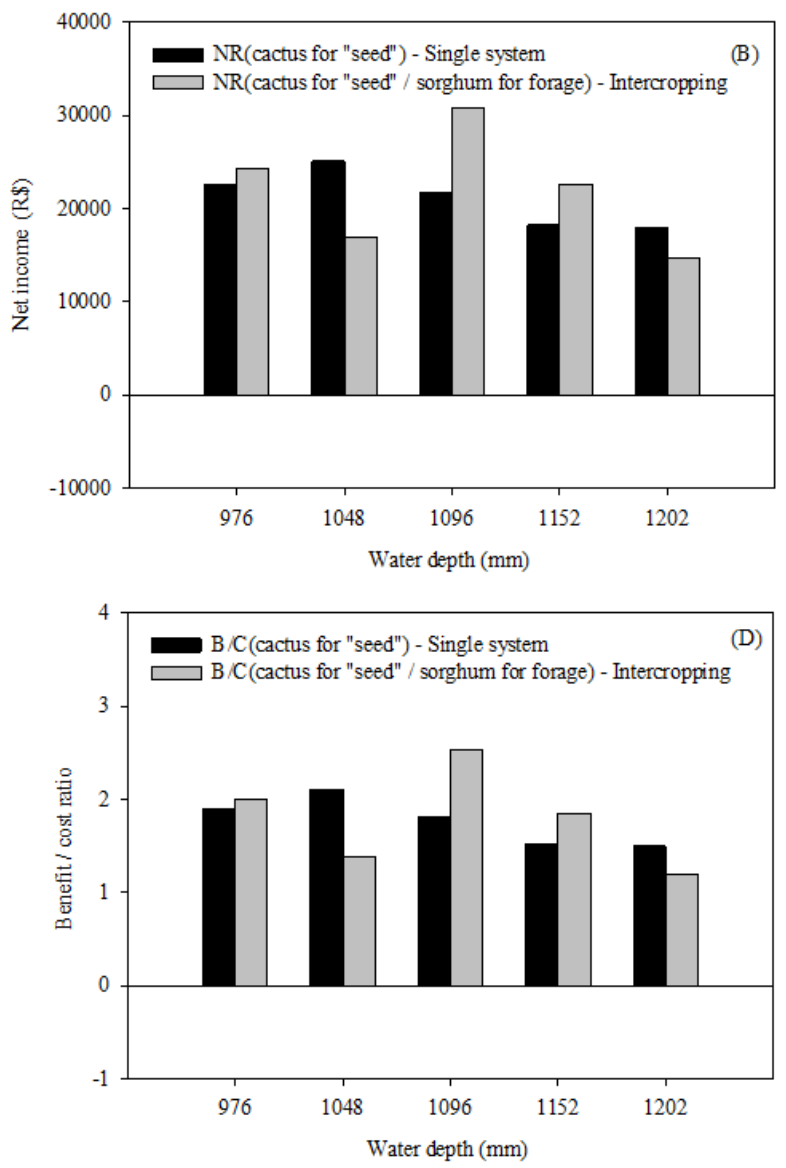

Figure 5. Net income (A and $B$ ) and benefit/cost ratio (C and D) of forage cactus (O. stricta (Haw.) Haw.) single cropping system and intercropped with double aptitude forage sorghum (cv. IPA2502), in different supplementary irrigation depths with saline water plus rainfall $\left(976,1,048,1,096,1,152\right.$, and 1,202 $\left.\mathrm{mm} \mathrm{year}^{-1}\right)$ in the Brazilian semi-arid region. Cactus and sorghum are sold as forage or cactus is produced for seeds.

The sale of cladodes as "seed" (Figure 5B, D) resulted in $\mathrm{B} / \mathrm{C}$ ratios $>1.77$ and 1.79 , respectively, for the single cropping and intercropping system, in the first year of the irrigation system. This shows that each R\$ 1.00 of investment in the irrigated forage cactus production system generated an average return of $\mathrm{R} \$ 1.78$. In the single cropping system, the $655-\mathrm{mm}_{\text {year }}{ }^{-1}$ supplementary irrigation depth presented higher $\mathrm{RL}$ and $\mathrm{B} / \mathrm{C}$ ratio values, followed by a slight reduction. In the intercropping system did not show superior performance compared to the single cropping system (Figure 5B, D), which may be associated with the effects of the intercropping on the number of cladodes assigned for being sold as "seed". In this present study, we assumed that only the cladodes of $1^{\text {st }}$ and $2^{\text {nd }}$ orders were sold as "seed".

\section{CONCLUSIONS}

Forage cactus and sorghum intercropping irrigated with saline water significantly increased the dry matter yield of the production system, mainly due to higher sorghum yields. 
An increase of irrigation depths of saline water between 583 and $809 \mathrm{~mm}$ year $^{-1}$ promoted a linear increase in dry matter production in the intercropping system.

Because cactus and sorghum were assigned for sale as forage, profitability was recognizable from the $2^{\text {nd }}$ year of implementation of the drip irrigation system, while with the sale of the cactus as "seed" and the sorghum as forage, economic return was verified within the first year.

Overall, the intercropping system promoted greater profitability than single forage cactus cropping.

\section{ACKNOWLEDGMENTS}

We thank the CNPq for financial support (no. 475279/2010-7) and the FACEPE for granting a scholarship to the first author.

\section{REFERENCES}

ALBUQUERQUE, S. G.; RAO, M. R. Espaçamento da palma forrageira em consórcio com sorgo granífero e feijão-de-corda no Sertão pernambucano. Revista da Sociedade Brasileira de Zootecnia, Viçosa, v. 26, n. 4, p. 645-650, 1997.

ALLEN, R. G. et al. Crop evapotranspiration: guidelines for computing crop water requirements. Rome: FAO, 1998. 310 p. (Irrigation and Drainage, $56)$.

ARAÚJO, A. C. et al. Indicadores agroeconômicos na avaliação do consórcio algodão herbáceo + amendoim. Ciência e Agrotecnologia, Lavras, v. 32, n. 5, p. 1467-1472, 2008.

ARAÚJO PRIMO, J. T. et al. Calibração de sondas capacitivas, funções físico-hídricas e variação do armazenamento de água em um argissolo cultivado com palma forrageira. Revista Ceres, Viçosa, v. 62, n. 1, p. 20-29, 2015.

BARBOSA, F. S. B. et al. Yield and ion content in maize irrigated with saline water in a continuous or alternating system. Ciência Rural, Santa Maria, v. 42, n. 10, p. 1731-1737, 2012.

BEZERRA, A. P. A. et al. Rendimento, componentes da produção e uso eficiente da terra nos consórcios sorgo x feijão-de-corda e sorgo x milho. Revista Ciência Agronômica, Fortaleza, v. 38, n. 1, p. 104-108, 2007.

CONSOLI, S.; INGLESE, G.; INGLESE, P. Determination of evapotranspiration and annual biomass productivity of a cactus pear (Opuntia ficusindica L. (Mill.)) orchard in a semiarid environment. Journal of Irrigation and Drainage Engineering, Amsterdam, v. 139, n. 1, p. 680-690, 2013.

CONY, M. A.; TRIONE, S. O.; GUEVARA, J. C. Macrophysiological responses of two forage Opuntia species to salt stress. Journal of the Professional Association for Cactus Development, Chapingo, v. 8, n. 1, p. 52-62, 2006.

DUBEUX JÚNIOR, J. C. B. et al. Productivity of Opuntia ficus-indica (L.) Miller under different N and $\mathrm{P}$ fertilization and plant population in north-east Brazil. Journal of Arid Environments, Amsterdam, v. 67, n. 1, p. 357-372, 2006.

FAN, Z. et al. Yield and water consumption characteristics of wheat/maize intercropping with reduced tillage in an Oasis region. European Journal of Agronomy, Amsterdam, v. 45, n. 1, p. 52 $-58,2013$.

FARIAS, I. et al. Manejo de colheita e espaçamento da palma forrageira em consórcio com sorgo granífero no Agreste de Pernambuco. Pesquisa Agropecuária Brasileira, Brasília, v. 35, n. 2, p. $341-347,2000$

FERNANDES, A. L. T.; SANTINATO, R.; FERNANDES, D. R. Irrigação na cultura do café. 2. ed. Uberaba, MG: O Lutador, 2008. 476 p.

FLORES-HERNÁNDEZ, A. et al. Yield and physiological traits of prickly pear cactus 'nopal' (Opuntia spp.) cultivars under drip irrigation. Agricultural Water Management, Amsterdam, v. 70, n. 1, p. 97-107, 2004

GUIMARÃES, M. J. M. et al. Cultivation of forage sorghum varieties irrigated with saline effluent from fish-farming under semiarid conditions. Revista Brasileira de Engenharia Agrícola e Ambiental, Campina Grande, v. 20, n. 5, p. 461-465, 2016.

LACERDA, C. F. et al. Soil salinization and maize and cowpea yield in the crop rotation system using saline waters. Engenharia Agrícola, Jaboticabal, v. 31, n. 4, p. 663-675, 2011.

MIRITI, J. M. et al. Yield and water use efficiencies of maize and cowpea as affected by tillage and cropping systems in semi-arid Eastern Kenya. Agricultural Water Management, Amsterdam, v. 115, n. 1, p. 148-155, 2012.

SANTOS, N. C. B. et al. Análise econômica do consórcio feijoeiro e milho-verde. Revista Brasileira de Milho e Sorgo, Sete Lagoas, v. 8, n. 1, p. 1-12, 2009. 
SILVA, G. S. et al. Desempenho agronômico de algodão orgânico e oleaginosas consorciados com palma forrageira. Revista Brasileira Engenharia Agrícola Ambiental, Campina Grande, v. 17, n. 9, p. $975-981,2013$.

SILVA, J. L. A. et al. Uso de águas salinas como alternativa na irrigação e produção de forragem no semiárido nordestino. Revista Brasileira de Engenharia Agrícola e Ambiental, Campina Grande, v. 8, Sup., p. 66-72, 2014.

SILVA, T. G. F. et al. Crescimento e produtividade de clones de palma forrageira no semiárido e relações com variáveis meteorológicas. Revista Caatinga, Mossoró, v. 28, n. 2, p. 10-18, 2015.

VIEIRA, G. H. S. et al. Custo da irrigação do cafeeiro em diferentes tipos de equipamentos e tamanhos de área. Engenharia na Agricultura, Viçosa, v. 19, n. 1, p. 53-61, 2011. 